\title{
Roles of Proteins/Enzymes from Animal Sources in Food Quality and Function
}

\author{
Chenyan Lv ${ }^{1}$, Chen $\mathrm{Xu}^{1,2,3}{ }^{1}$, Jing Gan ${ }^{2}$, Zhenghui Jiang ${ }^{3}$, Yumeng Wang ${ }^{1}$ and Xueli Cao ${ }^{1, *}$ \\ 1 Beijing Advanced Innovation Center for Food Nutrition and Human Health, Beijing Technology and \\ Business University (BTBU), Beijing 100037, China; 2019023@cau.edu.cn (C.L.); xuchen5140@163.com (C.X.); \\ goodbai0427@163.com (Y.W.) \\ 2 College of Life Sciences, Yantai University, Yantai 264005, China; keaiganjing@126.com \\ 3 Beijing Key Laboratory of Functional Food from Plant Resources, College of Food Science and \\ Nutritional Engineering, China Agricultural University, Beijing 100083, China; zhenghui0124@126.com \\ * Correspondence: caoxl@th.btbu.edu.cn
}

Citation: Lv, C.; Xu, C.; Gan, J.; Jiang, Z.; Wang, Y.; Cao, X. Roles of Proteins/Enzymes from Animal Sources in Food Quality and Function Foods 2021, 10, 1988. https:/ /doi.org/ $10.3390 /$ foods 10091988

Academic Editor: Rotimi Aluko

Received: 22 July 2021

Accepted: 20 August 2021

Published: 25 August 2021

Publisher's Note: MDPI stays neutra with regard to jurisdictional claims in published maps and institutional affiliations.

Copyright: (C) 2021 by the authors Licensee MDPI, Basel, Switzerland. This article is an open access article distributed under the terms and conditions of the Creative Commons Attribution (CC BY) license (https:// creativecommons.org/licenses/by/ $4.0 /)$.

\begin{abstract}
Animal proteins are good sources of protein for human, due to the composition of necessary amino acids. The quality of food depends significantly on the properties of protein inside, especially the gelation, transportation, and antimicrobial properties. Interestingly, various kinds of molecules co-exist with proteins in foodstuff, and the interactions between these can significantly affect the food quality. In food processing, these interactions have been used to improve the texture, color, taste, and shelf-life of animal food by affecting the gelation, antioxidation, and antimicrobial properties of proteins. Meanwhile, the binding properties of proteins contributed to the nutritional properties of food. In this review, proteins in meat, milk, eggs, and fishery products have been summarized, and polysaccharides, polyphenols, and other functional molecules have been applied during food processing to improve the nutritional and sensory quality of food. Specific interactions between functional molecules and proteins based on the crystal structures will be highlighted with an aim to improve the food quality in the future.
\end{abstract}

Keywords: protein; animal food; food quality; interactions

\section{Introduction}

Animal foods are good source of "high quality" protein for humans, especially lean meat, milk, eggs, and fishery products [1]. Diet composition improvement represents a key factor to enhance the health status and welfare of animals [2,3] as well as to enhance productivity and performance in livestock $[4,5]$. Proteins have been widely used as food components in the food industry due to their nutritional value and functional properties [6]. In the past several years, chemical modifications such as oxidation and glycosylation have been developed to improve the functional properties [7]. It is worth mentioning that gelation, oxidation, and assembly of proteins occurred which may affect the texture, nutrition, and sensory properties of food during food processing and storage [8]. Recent research has mainly focused on the improvement of gelation, inhibition of oxidation and assembly of proteins. Taking advantage of the antioxidant properties of polyphenols, the protein-polyphenol interactions have been reported to help inhibit or slow down the oxidation of protein from meat [9], and further affect the gelation process.

The micro- and macroscopic structures of food determine the behaviors of food. Proteins, especially myofibrillar protein in meat, contribute most to the formation of three-dimensional network structure in processed meat products, which will help to hold water inside and confer meat with a "juicy" taste. On the other hand, protein gelation also contributes to the quality of dairy products [10]. More interestingly, the gelation process can be improved by other molecules such as polysaccharides and polyphenols. Meanwhile, proteins in milk such as bovine serum albumin and lactoferrin play crucial 
roles in nutrient transportation [11]. The interactions between proteins and substances from environmental pollution or molecules produced during food processing may affect the transporting efficiencies to some extent [12].

In addition to the interactions between protein and small molecules, the antibacterial activities and enzymatic activities of proteins or enzymes also affect the product quality especially the storage stability and shelf-life. Therefore, it is imperative to summarize the roles of proteins from animal sources in food quality, and the effects of interactions between proteins and small molecules on food texture, and sensory and nutritional properties. As for the selection of research papers, we have analyzed the main proteins/enzymes affecting food qualities in each kind of food, which are myofibrillar protein, hemoglobin, whey protein, bovine serum albumin, casein, lactoferrin, lysozyme, ovalbumin, collagen, polyphenol oxidase, and ferritin (Table 1). Thus, we focused on these proteins and the interactions affecting quality. This review will not only provide guidelines for food processing to improve the quality of food products, but also make it possible to increase stability by regulating the properties of proteins or enzymes.

Table 1. Main proteins from animal sources and their relationship with product quality.

\begin{tabular}{|c|c|c|c|}
\hline Food Sources & Main Proteins & Relationships with Product Quality & References \\
\hline \multirow{5}{*}{ Meat } & Myofibrillar protein & \multirow{5}{*}{$\begin{array}{l}\text { Form heat-induced gel } \\
\text { Related to the water retention, chewiness and juiciness of meat products. } \\
\text { Related to the color of meat products. Influence gel properties, such as } \\
\text { water holding capacity. Indirectly affects meat tenderness. } \\
\text { Affect the texture, tenderness and water holding capacity of meat products. } \\
\text { Soluble, foaming, emulsifying, colorant, and nutritional supplement. } \\
\text { Foaming, solubility, emulsifying, gelling properties, and fat binder. }\end{array}$} & {$[13,14]$} \\
\hline & Sarcoplasmic protein & & {$[15,16]$} \\
\hline & Connective tissue & & [17] \\
\hline & Hemoglobin & & {$[18,19]$} \\
\hline & Plasma protein & & {$[18,20]$} \\
\hline \multirow{4}{*}{ Milk } & Whey protein & \multirow{4}{*}{$\begin{array}{l}\text { Emulsification, foaming, gelling, water binding properties. } \\
\text { Used as thickener, stabilizers, and fat substitutes in yogurt. } \\
\text { Physiological model protein, foaming, emulsifying, gelling properties. } \\
\text { Solubility, emulsifying, gelling, foaming, stability. Can be used to make } \\
\text { food films. } \\
\text { Biological activities: iron metabolism regulation, immune regulation, } \\
\text { antibacterial, antitumor, anti-inflammatory. Can be used as iron solubilizer. }\end{array}$} & \\
\hline & Bovine serum albumin & & [24] \\
\hline & Casein & & {$[25-27]$} \\
\hline & Lactoferrin & & {$[28,29]$} \\
\hline \multirow{4}{*}{ Egg } & Egg white proteins & $\begin{array}{l}\text { Gelling, water holding capacity, foaming and emulsifying properties. Can } \\
\text { be used as thickener to give the product good taste and texture. Enhance } \\
\text { the nutritional level. Can be used as food packaging film. }\end{array}$ & {$[30,31]$} \\
\hline & & Gelling, emulsification, film formation. & \\
\hline & Egg yolk proteins & $\begin{array}{c}\text { Can be used as gelata, adhesive or color former to improve the nutritional } \\
\text { value, flavor and taste of the product. }\end{array}$ & {$[32,33]$} \\
\hline & Lysozyme & $\begin{array}{l}\text { Antibacterial activity. } \\
\text { Extend the shelf life of food. }\end{array}$ & [34] \\
\hline \multirow{5}{*}{ Fishery products } & Collagen & Used as emulsifier, foaming agent, stabilizer and nutrients in the product. & {$[35,36]$} \\
\hline & Ferritin & Can be used as iron supplement. & {$[37]$} \\
\hline & Polyphenol oxidase & Cause melanosis of crustaceans. & [38] \\
\hline & Transglutaminase & Improve functional properties of proteins, such as gelation. & {$[39,40]$} \\
\hline & Cathepsins & Promoting degradation of myofibrillar protein. & [41] \\
\hline
\end{tabular}

\section{Proteins in Meat}

\subsection{Myofibrillar Protein}

Myofibrillar protein (MP) is the main protein in meat, accounting for $55-60 \%$ of the total [42], and predominately consisting of myosin, actin and some other regulatory proteins. Numerous myofibrils formed the muscle fibers and further joined together by connective tissue to form muscle. Most actin exists in the muscles as monomer polymerized double-stranded helical strands and can combine with the head of myosin to form thick filament. Myosin, which consists of two identical heavy chains, is an end-polarized doubleheaded long-chain molecule with helical structure. Assembly of myosin to filaments makes it hardly soluble, and limits its applications in the food industry. At present, strategies to inhibit or disrupt myosin formation have been widely developed [43]. In meat processing, heat-induced gelation of MP in muscle is a very important feature $[8,44]$, the first step of which is to denature and unfold the protein, so that the reaction group is exposed, 
especially the hydrophobic group of myosin. Then, the unfolded proteins are gathered, and the attraction and repulsion between adjacent polypeptide chains are balanced. After that, a stable three-dimensional network gel structure was finally formed [7]. As shown in Figure 1, the microstructure of gels heated under different pressures was observed by scanning electron microscopy, and thinner fibers were observed under $200 \mathrm{MPa}$ than under $400 \mathrm{MPa}$ [44]. Generally, the forces that maintain the protein structure and its gel network mainly include electrostatic interaction, hydrophobic interaction, hydrogen bond, disulfide bond, etc. As the main protein of MP, myosin is essential to form filamentous gel structure. Other MPs such as actin do not form gels, but have an important impact on the viscoelasticity of gels [13].
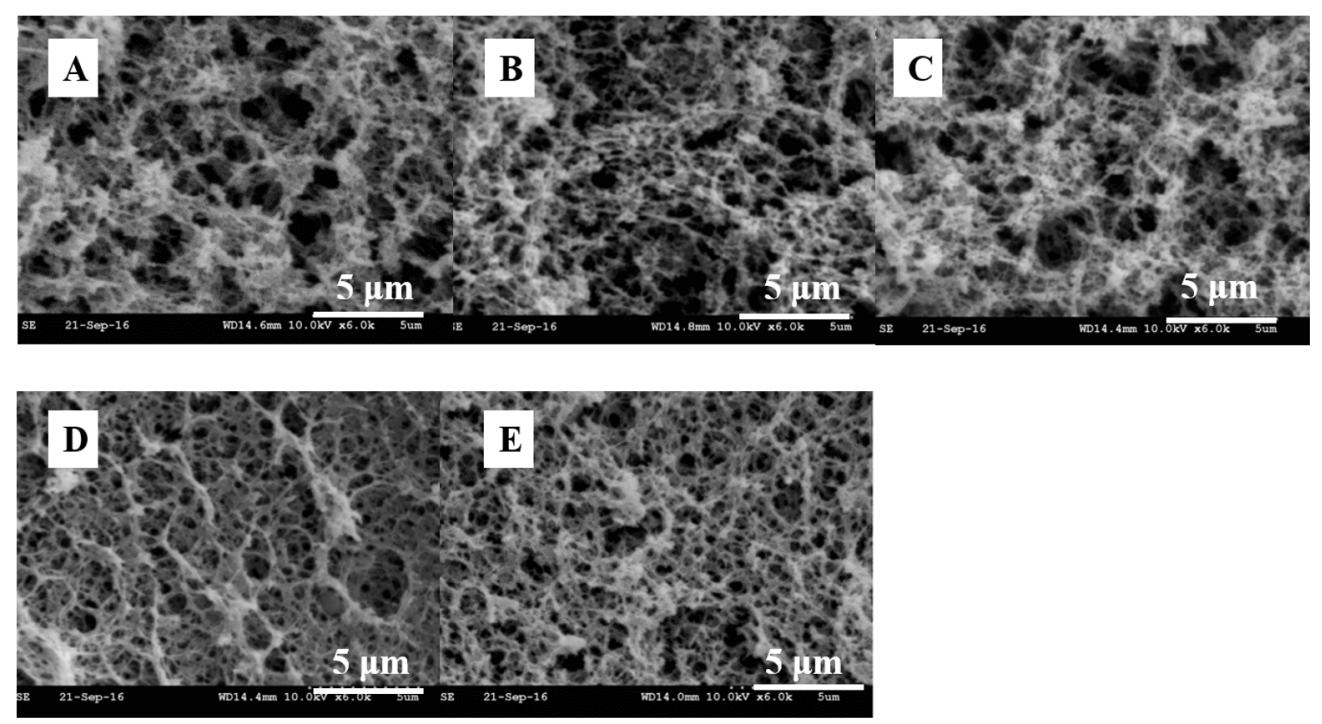

Figure 1. SEM microstructure of MPs gels induced by different combinations of pressure and heating; scale bars are $5 \mu \mathrm{m}$. (A). $0.1 \mathrm{MPa}, 75^{\circ} \mathrm{C}, 30 \mathrm{~min}$; (B). $200 \mathrm{MPa}, 20^{\circ} \mathrm{C}, 30 \mathrm{~min}$, then $0.1 \mathrm{MPa}, 75^{\circ} \mathrm{C}$, $30 \mathrm{~min}$; (C). $400 \mathrm{MPa}, 20^{\circ} \mathrm{C}, 30 \mathrm{~min}$, then $0.1 \mathrm{MPa}, 75^{\circ} \mathrm{C}, 30 \mathrm{~min}$; (D). $200 \mathrm{MPa}, 75^{\circ} \mathrm{C}, 30 \mathrm{~min}$; (E). $400 \mathrm{MPa}, 75^{\circ} \mathrm{C}, 30 \mathrm{~min}$. This figure was cited from reference [44].

At present, a variety of substances are used to improve the structure of MP gel to produce meat products with better quality and taste (Figure 2). Transglutaminase is a substance that promotes the widespread use of meat protein gels. A non-disulfide covalent bond is formed by transglutaminase between glutamine residues and lysine residues within and between proteins to cross-link protein molecules, thereby improving the properties of protein gels [45,46]. Moreover, some plant proteins which can cross-link with MP, form more stable gels by hydrophobic interactions and disulfide bonds, and improve the cooking yield of MP gels under the induction of glutamic amide transaminase, have been applied to improve the texture and sensory properties of products in meat processing [47-52].

In addition to macromolecules, polyphenols as small molecules also interact with MP in meat processing. Polyphenols not only have antioxidant and flavoring effects on MP, but also have important effects on gelation and emulsification [53]. Guo et al. [54] found that gallic acid can promote myosin cross-linking to form a denser and more uniform gel structure catalyzing by glucose oxidase. Moreover, the addition of catechins has been identified to increase the hydrophobicity of myofibrillar protein surface while reducing the thiol content, and Jia et al. [55] also confirmed the adverse effects of catechins on myofibrillar protein gel properties. By studying the effects of five phenolic compounds in mulberry polyphenols on the structure and functional properties of myofibrillar protein, Cheng et al. [56] found that all the five would affect the quality of meat products, in which caffeic acid and rutin played a key role. However, some polyphenols may play double functions during MP gelation [9,57]. A certain concentration of polyphenols (6 and $30 \mu \mathrm{mol} / \mathrm{g}$ protein of gallic acid and chlorogenic acid) can promote cross-linking between 
proteins and improve the performance of MP gel, but high concentrations of polyphenols (150 $\mu \mathrm{mol} / \mathrm{g}$ protein of gallic acid and chlorogenic acid) will lead to excessive covalent binding and excessive protein aggregation, which further inhibits the formation of gel.

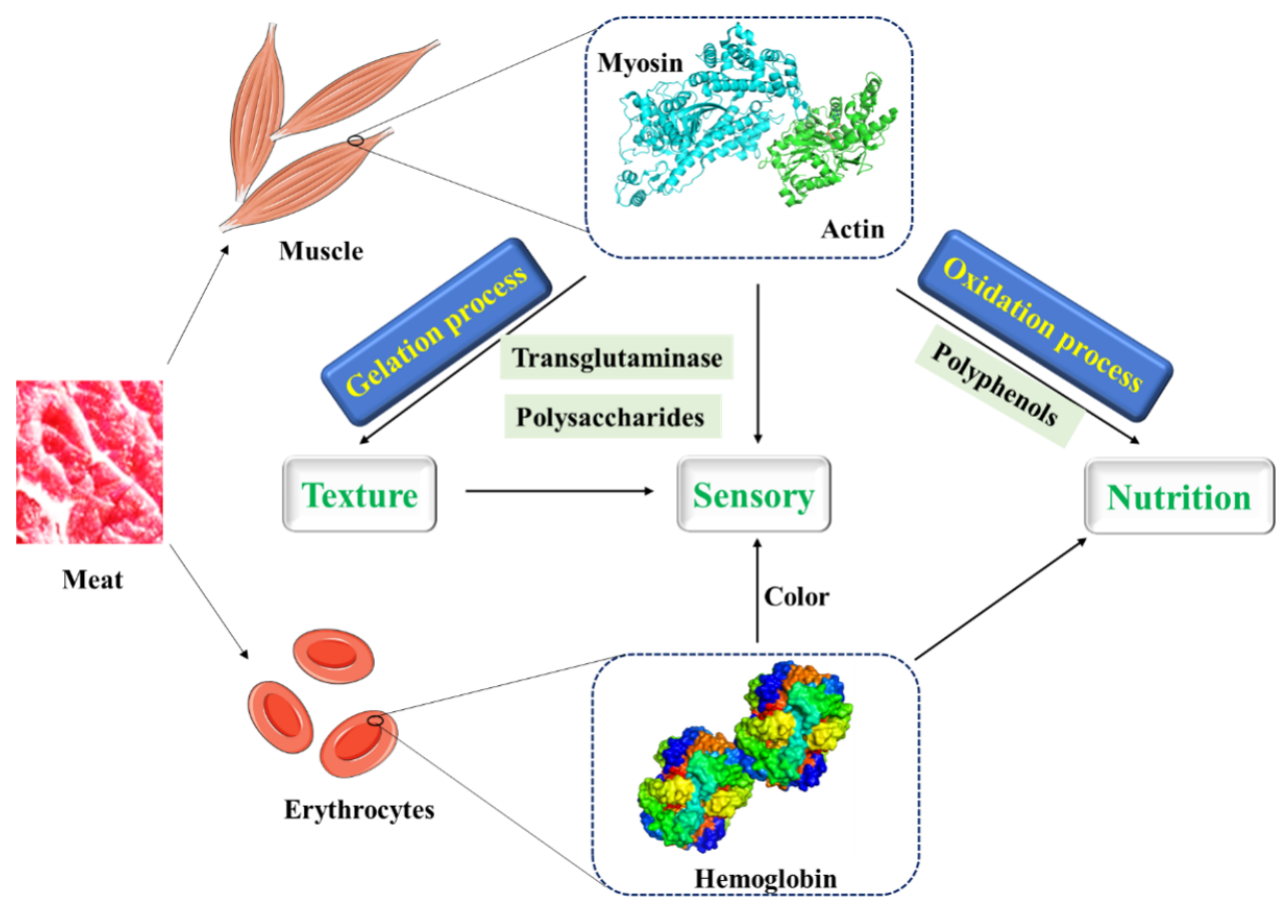

Figure 2. The interactions between proteins in meat and other molecules and their food texture, sensory, and nutritional effects.

\subsection{Hemoglobin}

As a secondary product of meat products, blood contains a substantial amount of highquality proteins that are not used $[58,59]$. Hemoglobin as the main component of protein in blood is composed of globin and porphyrin iron, and is rich in iron ions and amino acids. It can be used as a natural iron supplement and has the characteristics of easy absorption [19]. Hemoglobin has good solubility, emulsifying, foaming, and swelling properties, but its application in food is limited due to poor stability, dark color and metallic flavor [18]. By means of Maillard reaction, acetylation, deamidation, and succinylation, the structure of protein can be changed to improve its properties and function. Maillard reaction, which does not require additional chemicals, is considered to be the best method to improve the functional properties of food proteins [6]. Unlike Maillard reaction, adding glucose as reducing agent, niacin or nicotinamide as a chelating agent to porcine hemoglobin for spray drying can effectively prevent hemoglobin from self-oxidation and stabilize color [60]. Meanwhile, nitrosohemoglobin as a colorant can partially replace nitrite to improve the safety of meat products. After glycosylation, the stability of nitrosohemoglobin will be improved [61,62]. Liquid or dry blood treated with carbon monoxide can also be used as colorants in meat products, which has been proved to be feasible in mortadella $[63,64]$. More importantly, tea polyphenols can also affect the stability and color of hemoglobin, which is connected with the concentration of tea polyphenols [65]. At low concentrations, tea polyphenols can inhibit the oxidation of heme iron and maintain the hemoglobin color. High concentrations of tea polyphenols may lead to hemoglobin structural damage and heme iron exposure, thereby promoting hemoglobin oxidation discoloration.

In order to improve the utilization rate of hemoglobin, researchers decolored the hemoglobin and separated the globin by acidified acetone, carboxymethyl cellulose, sodium alginate and enzymatic hydrolysis [66-69]. Silva [70] compared the effects of globin extracted by acidified acetone (AG) and carboxymethyl cellulose (CG) and sodium caseinate (CA) as emulsifier agent on the quality characteristics of raw and cooked ham pâté. It was 
found that CG increased the salt-soluble protein content and the stability, CA increased the salt-soluble protein content and water holding capacity, and AG was unfavorable for these three parameters. More interestingly, Shi et al. found that as a histidine-specific protease, Aspergillus glutamic acid peptidase (AGP) could effectively decolor hemoglobin, and the AGP-decolored hemoglobin hydrolysates (AGP-Hb) had good emulsification, foaming, and water binding.

\subsection{Interactions between Meat Protein and Other Factors Affecting the Quality of Meat Product}

Meat is a very efficient deliverer of protein. In addition to fresh meat, meat is usually further processed to improve the sensory quality and to extend their shelf life. During food processing, large amounts of polysaccharides such as $\mathrm{k}$-carrageenan and flaxseed gum have been used in comminuted meat products to improve their functional properties such as emulsification, fat, and water binding capacity, while improving their texture and appearance.

In low-fat meat products, polysaccharides acting as water binders affect the thermal transition temperatures of meat proteins by interacting with meat protein. The electrostatic force in nature is the principal force responsible for these interactions. Meanwhile, by studying the thermal properties, dynamic rheological properties, texture and microstructure of salt-soluble meat protein and flaxseed gum, it was found that the interaction between salt-soluble meat protein and flaxseed gum occurred, and the main force for the formation and stabilization of protein-polysaccharide gels seemed to be electrostatic force [71,72]. The gel formed by flaxseed gum is thermoreversible, which is significantly related to the flavor release, perception of "juiciness" and oral retention times of meat products [71].

In addition, $\mathrm{k}$-carrageenan as a linear sulphated polysaccharide is usually added to canned meats and pet foods as a gelatinizer. The thermal reversible gel properties of carrageenan affect the function of meat products, which are important to the sensory quality of meat. Carrageenan is dissolved in the whole meat during hot processing and solidified during cooling, which can improve water retention, texture, and consistency of comminuted meat products [73]. However, instead of chemically interacting with meat proteins, carrageenans increased the water-holding capacity of meat emulsions by physically holding water in the interstitial spaces of the protein-gel network. In practical application, other factors may affect the properties of meat protein as well. During the cooking process, changes in quaternary, tertiary, and secondary structure of proteins occur, which may further induce the changes in intra/intermolecular interactions. In sodiumreduced chicken breast myofibrillar protein gel, high pressure processing and calcium have been used to increase the water holding capacity [74]. Moreover, in emulsified meat products such as sausages, phosphate elimination affected the gelling characteristics of the products, and egg or pea addition remediated the quality loss [75]. More importantly, two transglutaminase enzymes were used in the restructured beef steaks to create covalent linking between meat proteins and improve the quality [76].

\section{Proteins in Milk}

\subsection{Whey Protein}

Whey proteins are milk proteins (mainly $\beta$-lactoglobulin and $\alpha$-lactalbumin) that are widely used in food design due to a variety of functionalities, including: water binding, gelation, emulsification, and foaming [77]. In food processing, whey proteins are usually denatured due to heat treatments and thereby they aggregate, either in self-aggregation or with other food particles [78,79]. Through extensive research, it has been shown that the interactions between whey proteins and small molecules can change their molecular structures and the physico-chemical properties [79], supporting their applications in food.

Most chitosans, which have been shown to effectively reduce the cholesterol blood level in animals and humans by strongly binding to the negatively charged bile acids, have the ability to interact with whey protein in milk [80]. At low $\mathrm{pH}$, a weak carbohydrateprotein interaction is formed between chitosan and whey protein isolate, both of which are 
positively charged. When the $\mathrm{pH}$ is raised to 6.0 , where the protein should be negatively charged, a much stronger interaction occurs due to electrostatic attraction between them, indicating that $\mathrm{pH}$ plays an overwhelming role in this complex system [10]. Therefore, these interactions can help separating whey protein during diary processing. Meanwhile, as a gelled agent, carrageenan is commonly used in the production of milk-based desserts. The addition of $k$-carrageenan to whey protein-based desserts affects gel formation and caused an even higher storage modulus than milk-based desserts, possibly due to the interactions between whey proteins and $\mathrm{k}$-carrageenan at different $\mathrm{pH}$ values. At low $\mathrm{pH}$, especially after heating, the whey protein will be exposed to a large number of hydrophobic groups to form large aggregates, which is the result of strong interactions with k-carrageenan. In contrast, electrostatic repulsions between polysaccharide molecules and the negatively charged protein occurred at high $\mathrm{pH}$. Therefore, optimal conditions help the production of highly digestible, light-colored whey protein components. In addition, phenolic-rich foods such as coffee and fruit juices are often consumed together with milk. Milk protein can affect the bioavailability of polyphenols through their interactions. Consistent with this idea, it has been shown that the phenolic acids (such as chlorogenic acid, ferulic acid, caffeic acid, and coumalic acid) can not only quench the fluorescence of $\beta$-lactoglobulin and $\alpha$-lactalbumin by static quenching but also significantly affect the secondary structure of $\beta$-lactoglobulin and $\alpha$-lactalbumin. More specifically, phenolic acids were proved to interact with the $\mathrm{C}=\mathrm{O}$ and $\mathrm{C}-\mathrm{N}$ groups of the structural subunits of whey protein [81]. As a consequence, the interaction between whey protein and other molecules not only affects the application of whey protein in the food industry but also the bioavailability (Figure 3).

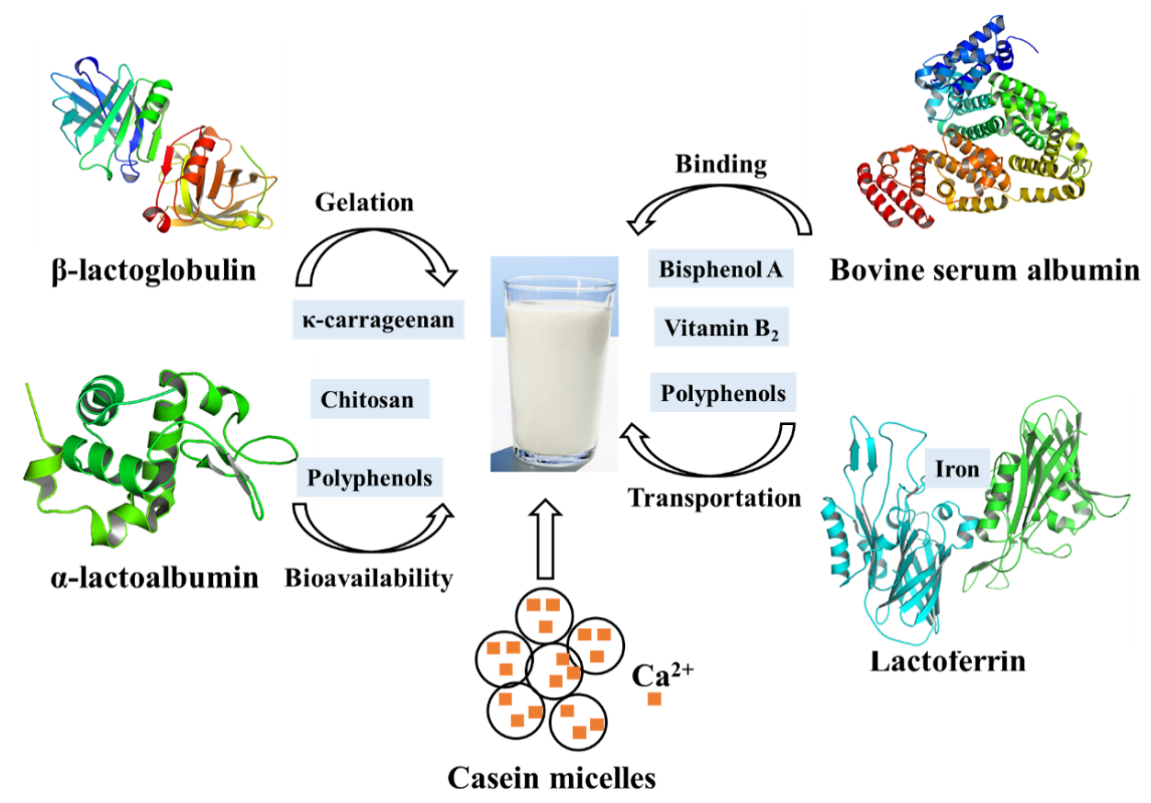

Figure 3. Main proteins in milk and their contributions to the quality of dairy products.

\subsection{Bovine Serum Albumin}

Bovine serum albumin (BSA) is a large globular protein with two tryptophan residues, which is highly sensitive to the local environment [82]. Various studies over the past few decades have shown that in the presence of monovalent salts, BSA can form complexes with polysaccharides, surfactants, and other charged polymers [83]. Recently, interactions between BSA and small molecules have attracted considerable attention, due to their desirable and undesirable role in food stuff.

Bisphenol A (BPA), one of the most widely disseminated endocrine-disrupting chemicals and acrylamide AA, listed as a possible human carcinogen in carbohydrate-rich foods both have bad effects on wildlife and human health [84]. Research on the interaction between BSA and BPA or AA indicated that the binding of BPA and AA with BSA responded 
to the partition law and the secondary structure of BSA changed obviously when BPA and AA were present. The hydrophobic effect is the main factor that induces BPA binding to BSA, and the hydrogen bond between them promotes the interaction between AA and BSA [12]. Accordingly, the binding ratio of vitamin B2 to BSA has been reduced by more than $70 \%$ and almost one half, showing that BPA or AA inhibited the transport function of BSA. In addition, dietary flavonoids and stilbenes as important phytonutrient components found in vegetables, fruits, nuts, and tea have been widely studied. The flavonol moiety and the 5,7-dihydroxylation at the A-ring are important structural features with significant antioxidant activity [85]. The binding ability of four differently substituted B-ring hydroxylation flavonols and a flavonol glycoside to BSA by quenching the intrinsic fluorescence of the protein was studied [86]. As expected, the binding affinity increased with the number of hydroxyl groups on the B-ring and the hydrogen bond force play an important part in the binding of flavonols to BSA. Moreover, polyphenols-protein interaction can be used to regulate the bioavailability of polyphenols. Smith et al. found that binding of polyphenols to albumin reduced their prooxidant activity [87]. Thus, interactions between them can weaken the antioxidant capacity of polyphenols, thereby affecting their application in food. Moreover, 5-Spiro- $3^{\prime}$-piperidine- $2^{\prime \prime}$-spiro- $3^{\prime \prime}$-indole- $4^{\prime}, 2^{\prime \prime}$-diones (SPSD), an anti-tumor drug, has the ability to bind BSA through the hydrophobic force, van der Waals interactions, hydrogen bonds, and the electrostatic interaction, which can induce a conformational change of BSA. In addition, tricyclo [3.3.1.1(3, 7)] decane-1-amine (Amantadine) as an antivirotic drug can bind to BSA molecules and efficiently quench its intrinsic fluorescence [88]. In this way, the interaction between the Amantadine Schiff-Bases and BSA molecules can be strengthened by the methoxy group or the chloride atom. These works will contribute to the understanding of the mechanism of interactions between small molecules and BSA, and contribute to the future development of its potential biological, pharmaceutical, and physiological implications.

\subsection{Casein}

Caseins, the major proteins in milk, are a family of related phosphoproteins and consist of submicelles which in turn are aggregates of three calcium-insoluble proteins $(\alpha S 1$, $\alpha \mathrm{S} 2$ and $\beta$-casein) and one calcium-soluble protein $\kappa$-casein [89]. The calcium-insoluble caseins are usually considered to be located predominantly within the micelles, while $\mathrm{K}$-casein is thought to coat the micelle, serving to stabilize the structure [90]. Additionally, the calcium-insoluble caseins are highly phosphorylated, and they interact with calcium phosphate interacts through their phosphate groups. In this way, the casein micelles carry a large number of (usually highly insoluble) calcium phosphate into milk and keep it suspended. However, the removal of subcritical amounts of $\mathrm{Ca}^{2+}$ from casein micelles with EDTA releases soluble casein, suggesting that $\mathrm{Ca}^{2+}$ removal initially dissociates weakly bound caseins from the micelle without destroying the micelle size determining framework. Generally, the minerals and caseins in milk are in dynamic equilibrium between the micellar (pelleted components) and serum phases (non-pelleted components) [91]. Temperature, $\mathrm{pH}$, and mineral salts or calcium chelators can affect the partitioning of the components [91]. Studies of calcium-chelating agents showed that the amount of colloidal calcium phosphate removed from casein micelles limited the reversibility of calcium phosphate micelle dissolution and formation. Furthermore, addition of casein to milk has been proved to increase the Ca absorption in young rats [92].

On the other hand, casein has a wide range of uses in food industry, especially in cheese. The milk salts, $\mathrm{Ca}^{2+}$ and $\left(\mathrm{PO}_{4}\right)^{3-}$, play an important role in the rennet coagulation of milk and in the structure and buffering of cheese by the neutralization of negatively charged residues on casein and aggregation of renneted micelles [93]. Addition of low concentrations of $\mathrm{Ca}^{2+}$ also increases gel firmness, which is important for the cheese texture. Moreover, the functional properties of casein can be changed by modification. Casein modified by freezing or ultrasound exhibited better emulsifying capacity and water absorption capacity, helping to extend the shelf life of the products (Figure 4) [94]. The 
partial replacement of casein in cheese by modified caseins can improve the microbial stability and shelf life of the cheeses. More interestingly, the interactions between casein and tannic acid have been further applied in food packaging, the results of which suggest that tannic acid is an effective crosslinking agent for casein protein, and can improve the water resistance of film [95].
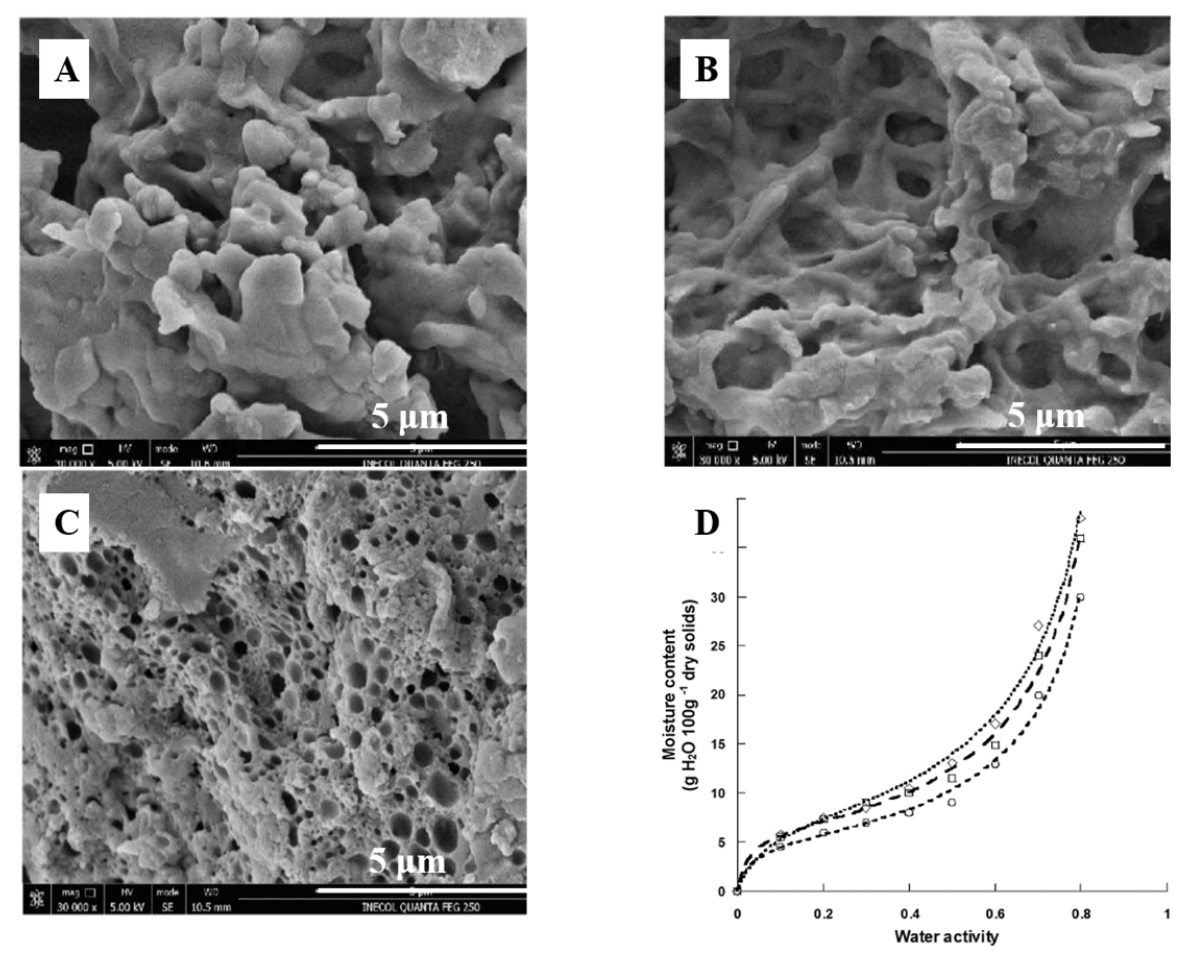

Figure 4. The ultrasound and freezing produced significant changes in the microstructure of casein, which produced a change in its physicochemical and functional properties. Micrographs obtained by scanning electron microscopy of (A) Unmodified acid casein (UAC), (B) Freezing with nitrogen (FMC), and (C) Ultrasound (UMC). Magnification is 30,000; scale bars are $5 \mu \mathrm{m}$. (D). Sorption isotherms of $\operatorname{UAC}(\bigcirc), \operatorname{UMC}(\square)$, and FMC $(\diamond)$. This figure was cited from reference [94].

\subsection{Lactoferrin}

Lactoferrin (LF), a glycoprotein that binds to $\mathrm{Fe}^{3+}$, was first found in milk and then in other human epithelial secretions and barrier body fluids. In breast milk, only $15 \%$ of LF is saturated by iron. Like the transferrin, lactoferrin has a molecular weight of $76 \mathrm{kDa}$, which binds two metal ions and is synergistic with two bicarbonate ions [11]. LF's stronger iron-binding affinity makes it the only transferrin capable of retaining this metal over a wide range of $\mathrm{pH}$ values, even the extremely acidic $\mathrm{pH}$ [96]. The binding metals are not only the $\mathrm{Fe}^{3+}$ ions, but also $\mathrm{Cu}^{2+}, \mathrm{Zn}^{2+}$ and $\mathrm{Mn}^{2+}$ ions. LF has the ability to reversibly bind to $\mathrm{Fe}^{3+}$, so it has different three-dimensional conformations (Apo-LF or Holo-LF) according to whether it binds to $\mathrm{Fe}^{3+}$. Apo-LF can be rapidly degraded into small peptides by trypsin, while the iron-saturated form is relatively resistant to long-term trypsin digestion, producing only large fragments and retaining its iron-binding ability.

In addition, LF is a multifunctional protein because of its net positive charge and distribution in various tissues [29]. It is involved in a variety of physiological functions, including: regulation of iron absorption; antioxidant, anticarcinogenic and anti-inflammatory properties; immune response; and protection against microbial infection, which is the most widely studied function so far [29]. Due to the direct interaction with the bacterial surface, by carrying the $\mathrm{Fe}^{3+}$ ion, LF restricts the utilization of nutrients at the infection site by bacteria, and inhibits the growth of these microorganisms and the expression of virulence factors, thus achieving an antibacterial effect. 
Overall, in terms of safety, bioavailability, and productivity, LF has been identified as a natural iron solubilizer and nutraceuticals for food products and plays an antibacterial role in the food industry.

\section{Proteins in Egg}

\subsection{Lysozyme}

As one of the least expensive forms of protein, fresh shell eggs are among the most nutritious daily foods. However, shell eggs' internal quality deteriorates, and bacteria grow easily during storage. Egg-white lysozyme is an important component in the prevention of bacterial growth in hen eggs and is usually used as a preservative to inhibit the growth of deleterious organisms thus prolonging shelf life [97]. Lysozyme is a kind of enzyme that lyses the cell walls of certain Gram-positive bacteria as it splits the bond between $\mathrm{N}$-acetylmuramic acid and $\mathrm{N}$-acetylglucosamine of the peptidoglycan in the bacterial cell wall [98]. Despite the direct bacteriolytic action, it is reported that lysozyme had many other biological functions such as antiviral action to inactivate certain viruses by forming an insoluble complex, anti-inflammatory and antihistaminic actions, potentiation of antibiotic effects, and so on. Nevertheless, the peptidoglycan envelope of gram-negative bacteria is known to consist mainly of lipopolysaccharide (LPS) and is resistant to natural lysozyme, and lysozyme was not suitable for general antimicrobial use due to its limited lytic spectrum. However, it is not suitable for general antibacterial use due to its limited lysozyme spectrum. When lysozyme is used with other substances such as chitosan or glucan, its antibacterial spectrum may be enhanced [99]. Research on lysozymedextran conjugate prepared by Maillard reaction showed that it has obvious antimicrobial activity against both Gram-negative and Gram-positive bacteria. The antimicrobial activity of the lysozyme-dextran conjugate exhibits stable lysozyme antimicrobial activity for Gram-negative bacteria and excellent emulsifying properties to solubilize the outer membrane [100].

Furthermore, lysozyme-chitosan coating solutions could be effectively produced for use in preservation, extending the shelf life of eggs by delaying the loss of interior quality during storage [99]. Developing different perishable food coatings with different antioxidant and antimicrobial effects is the goal of future work.

\subsection{Ovalbumin}

Ovalbumin is the main protein in egg white with good foaming, emulsifying, and gelation. It is found that the interaction between lysozyme and ovalbumin occurred in a chimeric mode, which may be caused by hydrophobic bonds [101]. The interaction between them is reversible, forming a homeostasis. Although this interaction reduced the bacteriolytic activity of lysozyme, the foaming properties and foam stability of egg white protein were decreased without lysozyme [102] (Figure 5). The relationship between egg white proteins remains to be further studied.

Egg albumin is rich in disulfide bonds and thiol groups, and thin films can be formed by alkali and heat treatment [103]. Compared with commercial polylactic acid (PLA) film, egg white protein (EWP) film, which is produced by an extrusion and rolling process, has higher water permeability, rigidity, heat resistance, and oxygen barrier, which can be used as part of semi-solid and solid food packaging materials [104]. Huang [105] mixed egg white protein and $\mathrm{k}$-carrageenan to prepare edible composite films, and found that, with the increase of egg white protein content, the disorder degree of the composite film increased, the elongation at break and light transmittance increased, but the oxygen permeability, water vapor permeability and water soluble decreased. Compared with the commercial film, EWP/ $\mathrm{k}-\mathrm{C}$ composite film can effectively delay the oil rancidity. Tiimob [106] found that the addition of egg white protein into poly butylene adipate-coterephthalate (PBAT)/polylactic acid (PLA) blends could make the resulting film have a certain antibacterial effect, showing the potential of egg white for manufacturing food packaging materials. It is noteworthy that, in the production of oat noodles, wheat noodles 
and pasta, the addition of egg white can lower the cooking loss and increase the springinesss and resilience by influencing the water absorption and texture [31].

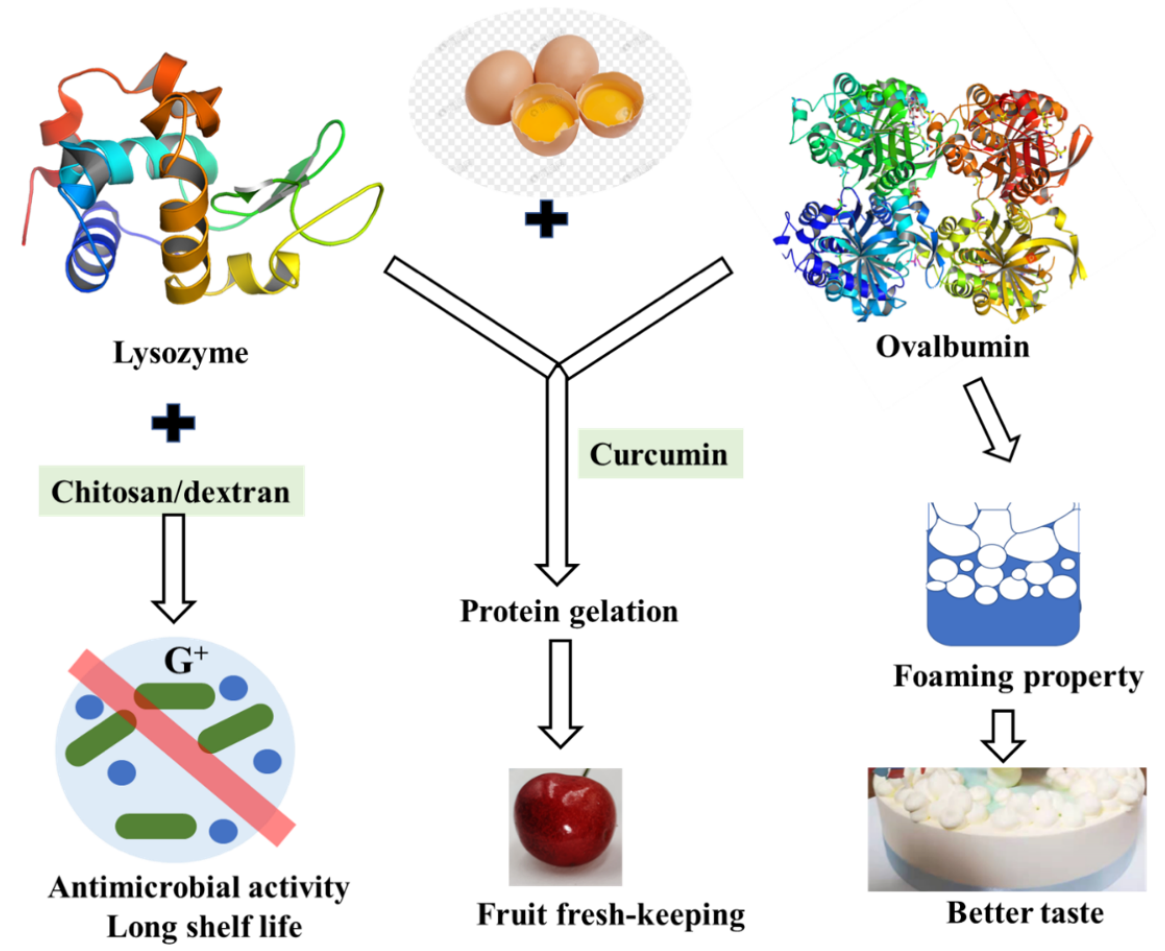

Figure 5. Functional proteins in eggs and their contribution to shelf-life and taste of food.

\section{Protein in Fishery Products}

\subsection{Collagen}

Texture determines the acceptance of seafoods by consumers and thus determines the marketability of seafoods, so it is considered as one of the important quality attributes of seafood. As the main component of connective tissue membranes, collagen in fish product muscles is responsible for the integrity of the fillets. Unlike other muscle foods, however, fishery products usually remove stiffness more quickly, eventually leading to widespread extensive softening of the flesh [107]. The initial steps in deterioration of raw fish during its storage on ice consist of hydrolytic reactions catalyzed by endogenous enzymes, which produce nutrients that allow bacteria proliferation [108].

During refrigeration, proteolysis may affect the texture changes, so special attention should be paid to it. Although opinions differ on the effect of collagen on flesh softening, the destruction of fine collagenous fibrils in the skeletal muscle of cod may be caused by endogenous collagenases and other proteases [109]. In general, specific collagenases initiate the initial attack on collagenous tissue. Once the initial cleavage has been achieved, other nonspecific proteases can pursue an attack [110].

Additionally, attempts have been made to control the seafood texture by inactivating the related enzymes, for example, high hydrostatic pressure [107]. Moreover, collagen as a main part of fishery products has been extensively applied in the food system and cosmetics. More efforts should be made to improve the quality of fishery products by modifying collagens.

\subsection{Polyphenol Oxidase}

Because of the existence of polyphenol oxidase, crustaceans such as shrimp, prawn, $\mathrm{crab}$, and lobster are prone to melanosis. Polyphenol oxidizes phenols to quinones, followed by nonenzymatic polymerization and autooxidation of quinones, resulting in the production of high molecular weight dark pigments [38]. Although melanosis does not 
cause damage to the human body, it reduces the economic value of products to a certain extent. Sulfite-based compounds, their derivatives and polyphenols can inhibit melanosis. Among them, natural plant polyphenols are safer and have been widely studied [111]. Calvo [112] found that all polyphenol extracts showed higher polyphenol oxidase inhibitory activity than sulfite by comparing the inhibitory effect of polyphenol extracts from five halophytes on diphenol oxidase of white shrimp, and Portulaca oleracea extract was the most effective one (Figure 6).

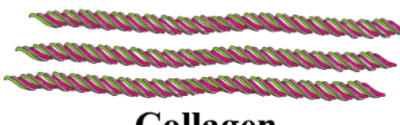

Collagen

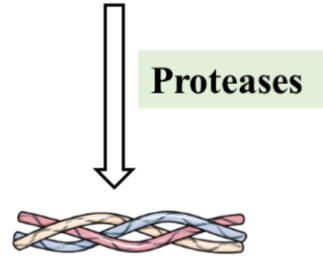

Texture

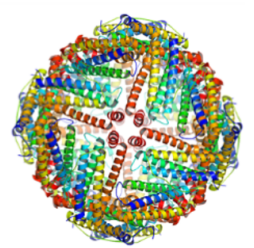

Ferritin
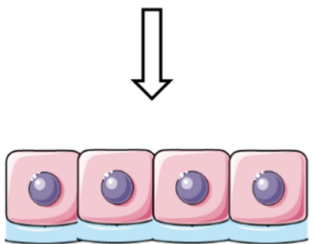

Increased iron absorption

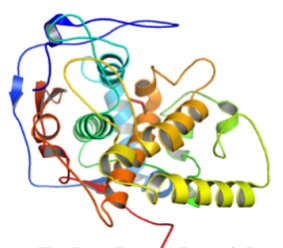

Polyphenol oxidase

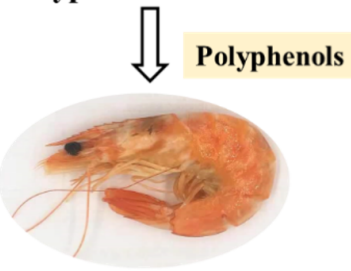

Melanosis inhibition

Figure 6. Specific proteins in fishery products that contributed to the texture, color, and nutrition.

\subsection{Ferritin}

Ferritin has a highly conserved conformation and is widely found in the animal and plant kingdom [113]. As an iron storage protein, ferritin plays a key role in maintaining cellular homeostasis. Moreover, in vertebrates, ferritin is responsible for resistance against oxidative stress, and increased level of ferritin is also a non-specific marker of inflammatory processes [114,115]. Similarly, in Pacific white shrimp, ferritin expression has been reported to be sensitive to $\mathrm{pH}$ treatment, which means ferritin expression levels may be indicators of the $\mathrm{pH}$ stress around the shrimp [116]. It is worth mentioning that purified recombinant ferritin cloned from black tiger shrimp Penaeus mondon can help to reduce the mortality in shrimp infected with Vibrio harveyi [117]. Exogenous injection of purified crustacean ferritin can help protect the hosts from microbial infection [118].

In New Caledonia, blue shrimp with orange gills has been observed in the past decade. The coloring appeared during processing and marketing, and significantly affected the quality and selling prices of shrimp. Lemonnier et al. showed that the coloration resulted from the iron that settled on the gill tissue surface [119], which suggested that free iron in the pond is bad for shrimp quality, and the intensity of the orange gills may be reduced by using ferritin to mobilize free iron. Additionally, ferritin from shrimp with high contents of iron inside can also be developed as iron supplements in the future.

\subsection{Crustacyanin}

In lobster crustacyanin, the bathochromic shift has attracted the attention of scientists for over 50 years. Color as a crucial factor affecting the quality of shrimp has been identified to relate with the function of crustacyanin (Figure 7). During cooking, the color of shrimp turns to red, mainly due to the denaturation of crustacyanin and release of astaxanthin. Therefore, the interactions between crustacyanin and chromophore seem to be important. In 2002, the first crystal structure of crustacyanin and astaxanthin were resolved, suggesting that the protein contacts and structural alterations may be responsible for color regulation [120]. In 2015, Gamiz-Hernandez et al. elucidated the mechanism underlying the color shift to be the electrostatic and steric effects of crustacyanin and astaxanthin [95]. Practical applications of this protein need to be further identified. 


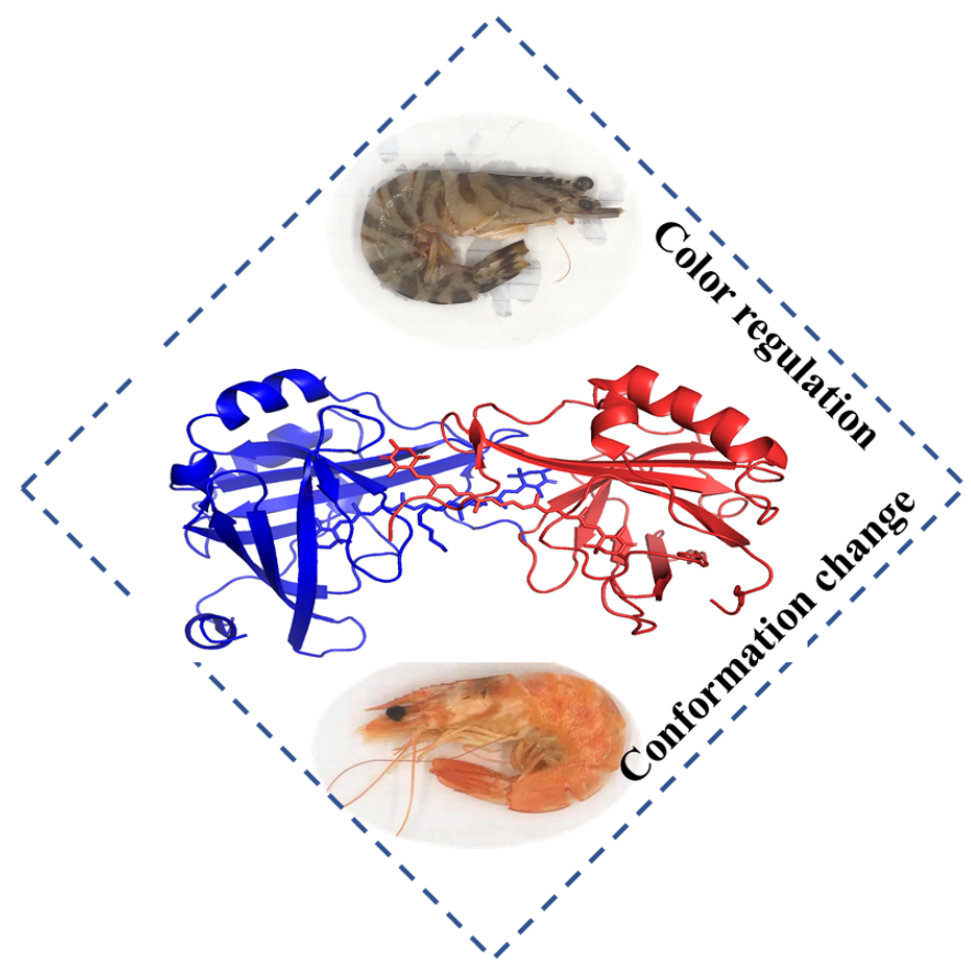

Figure 7. The interaction of crustacyanin and axtaxanthin affecting the color of shrimp.

\section{Conclusions}

Proteins from animal food contain almost all kinds of necessary amino acids, which make them the good sources of protein. In natural food, the properties of protein are closely related to the texture, shelf-life, color, and taste of food. As the food industry develops, other molecules such as polysaccharides, polyphenols, and enzymes have been used to enhance the specific properties of protein, and thus improve the quality of food. Although proteins from meat, milk, eggs, and fishery products and the potential interactions between protein and other molecules affecting food quality have been summarized in this review, there are several aspects that need to be further investigated. Firstly, various kinds of molecules have been reported to improve the gelation property of meat; it is necessary to find the crucial molecules that affect quality. Secondly, although the proteins in milk have been extensively studied, there are still other enzymes or functional factors contributing to the quality of dairy products. Thirdly, enzymes responsible for autolysis are crucial for fishery products; thus, their identification and inhibition are significant. Therefore, in the future, many more efforts should focus on identification of proteins/enzymes, and the specific interactions between proteins/enzymes and functional factors based on their crystal structures.

Author Contributions: Writing—original draft preparation, C.L.; Writing—review and editing, C.X., J.G., Z.J., Y.W.; Funding acquisition, X.C. All authors have read and agreed to the published version of the manuscript.

Funding: This research was funded by the grants from Beijing Advanced Innovation Center for Food Nutrition and Human Health (20181023).

Institutional Review Board Statement: Not applicable.

Informed Consent Statement: Not applicable.

Data Availability Statement: Not applicable.

Acknowledgments: We thank for suggestions provided by Guanghua Zhao, China Agricultural University.

Conflicts of Interest: The authors declare no conflict of interest. 


\section{References}

1. Barness, L.A. Dietary guidelines. Arch. Pediatr. Adolesc. Med. 1979, 133, 868. [CrossRef]

2. Abbate, J.M.; Macrì, F.; Capparucci, F.; Iaria, C.; Briguglio, G.; Cicero, L.; Salvo, A.; Arfuso, F.; Ieni, A.; Piccione, G.; et al. Administration of protein hydrolysates from anchovy (Engraulis encrasicolus) waste for twelve weeks decreases metabolic dysfunction-Associated fatty liver disease severity in ApoE ${ }^{-1-}$ mice. Animals 2020, 10, 2303. [CrossRef] [PubMed]

3. Abbate, J.M.; Macrì, F.; Arfuso, F.; Iaria, C.; Capparucci, F.; Anfuso, C.; Ieni, A.; Cicero, L.; Briguglio, G.; Lanteri, G. AntiAtherogenic Effect of 10\% Supplementation of Anchovy (Engraulis encrasicolus) Waste Protein Hydrolysates in ApoE-Deficient Mice. Nutrients 2021, 13, 2137. [CrossRef] [PubMed]

4. Monteverde, V.; Congiu, F.; Vazzana, I.; Dara, S.; Pietro, S.D.; Piccione, G. Serum lipid profile modification related to polyunsaturated fatty acid supplementation in thoroughbred horses. J. Appl. Anim. Res. 2017, 45, 615-618. [CrossRef]

5. Piccione, G.; Arfuso, F.; Fazio, F.; Bazzano, M.; Giannetto, C. Serum Lipid Modification Related to Exercise and Polyunsaturated Fatty Acid Supplementation in Jumpers and Thoroughbred Horses. J. Equine. Vet. Sci. 2014, 34, 1181-1187. [CrossRef]

6. Oliver, C.M.; Melton, L.D.; Stanley, R.A. Creating proteins with novel functionality via the maillard reaction: A review. Crit. Rev. Food Sci. Nutr. 2006, 46, 337-350. [CrossRef]

7. Zhao, X.; Xu, X.; Zhou, G. Covalent chemical modification of myofibrillar proteins to improve their gelation properties: A systematic review. Compr. Rev. Food Sci. Food Saf. 2021, 20, 924-959. [CrossRef]

8. Chen, B.; Guo, J.; Xie, Y.; Zhou, K.; Li, P.; Xu, B. Modulating the aggregation of myofibrillar protein to alleviate the textural deterioration of protein gels at high temperature: The effect of hydrophobic interactions. Food Chem. 2021, 341, 128274. [CrossRef]

9. Cao, Y.; Xiong, Y.L. Chlorogenic acid-mediated gel formation of oxidatively stressed myofibrillar protein. Food Chem. 2015, 180, 235-243. [CrossRef]

10. De Souza, H.K.; Bai, G.; Gonçalves, M.D.P.; Bastos, M. Whey protein isolate-chitosan interactions: A calorimetric and spectroscopy study. Thermochim. Acta 2009, 495, 108-114. [CrossRef]

11. Anderson, B.F.; Baker, H.M.; Norris, G.E.; Rice, D.W.; Baker, E.N. Structure of human lactoferrin: Crystallographic structure analysis and refinement at $2.8 \AA$ resolution. J. Mol. Biol. 1989, 209, 711-734. [CrossRef]

12. Zhang, Y.; Zhang, X.; Fei, X.; Wang, S.; Gao, H. Binding of bisphenol A and acrylamide to BSA and DNA: Insights into the comparative interactions of harmful chemicals with functional biomacromolecules. J. Hazard. Mater. 2010, 182, 877-885. [CrossRef]

13. Sun, X.D.; Holley, R.A. Factors influencing gel formation by myofibrillar proteins in muscle foods. Compr. Rev. Food Sci. Food Saf. 2011, 10, 33-51. [CrossRef]

14. Wang, X.; Wang, L.; Yang, K.; Wu, D.; Ma, J.; Wang, S.; Zhang, Y.; Sun, W. Radio frequency heating improves water retention of pork myofibrillar protein gel: An analysis from water distribution and structure. Food Chem. 2021, 350, 129265. [CrossRef]

15. Dai, Y.; Miao, J.; Yuan, S.; Liu, Y.; Li, X.; Dai, R. Colour and sarcoplasmic protein evaluation of pork following water bath and ohmic cooking. Meat Sci. 2013, 93, 898-905. [CrossRef]

16. Xia, M.; Chen, Y.; Guo, J.; Huang, H.; Wang, L.; Wu, W.; Xiong, G.; Sun, W. Water distribution and textual properties of heat-induced pork myofibrillar protein gel as affected by sarcoplasmic protein. LWT_Food Sci. Technol. 2019, 103, 308-315. [CrossRef]

17. Astruc, T. Connective tissue: Structure, function, and influence on meat quality. In Encyclopedia of Meat Sciences, 2nd ed.; Elsevier: Amsterdam, The Netherlands, 2014; pp. 321-328.

18. Toldrà, M.; Lynch, S.A.; Couture, R.; Álvarez, C. Blood proteins as functional ingredients. Sustain. Meat Prod. Process. 2019, 85-101. [CrossRef]

19. Pizarro, F.; Olivares, M.; Valenzuela, C.; Brito, A.; Weinborn, V.; Flores, S.; Arredondo, M. The effect of proteins from animal source foods on heme iron bioavailability in humans. Food Chem. 2016, 196, 733-738. [CrossRef]

20. Pares, D.; Toldra, M.; Saguer, E.; Carretero, C. Scale-up of the process to obtain functional ingredients based in plasma protein concentrates from porcine blood. Meat Sci. 2014, 96, 304-310. [CrossRef]

21. Komeroski, M.R.; Homem, R.V.; Schmidt, H.; Rockett, F.C.; Lira, L.; Farias, D.; Kist, T.L.; Doneda, D.; Rios, A.; Oliveira, V.R. Effect of whey protein and mixed flours on the quality parameters of gluten-free breads. Int. J. Gastron. Food Sci. 2021, $24,100361$. [CrossRef]

22. Fan, Y.; Peng, G.; Pang, X.; Wen, Z.; Yi, J. Physicochemical, emulsifying, and interfacial properties of different whey protein aggregates obtained by thermal treatment. LWT_Food Sci. Technol. 2021, 149, 111904. [CrossRef]

23. Torres, I.C.; Amigo, J.M.; Knudsen, J.C.; Tolkach, A.; Mikkelsen, B.; Ipsen, R. Rheology and microstructure of low-fat yoghurt produced with whey protein microparticles as fat replacer. Int. Dairy J. 2018, 81, 62-71. [CrossRef]

24. Sharma, L.G.; Pandey, L.M. Thermomechanical process induces unfolding and fibrillation of bovine serum albumin. Food Hydrocoll. 2020, 112, 106294.

25. Broyard, C.; Gaucheron, F. Modifications of structures and functions of caseins: A scientific and technological challenge. Dairy Sci. Technol. 2015, 95, 831-862. [CrossRef]

26. Atamer, Z.; Post, A.E.; Schubert, T.; Holder, A.; Boom, R.M.; Hinrichs, J. Bovine $\beta$-casein: Isolation, properties and functionality. A review. Int. Dairy J. 2016, 66, 115-125. [CrossRef]

27. Picchio, M.L.; Linck, Y.G.; Monti, G.A.; Gugliotta, L.M.; Minari, R.J.; Igarzabal, C.I.A. Casein films crosslinked by tannic acid for food packaging applications. Food Hydrocoll. 2018, 84, 424-434. [CrossRef] 
28. Li, C.; Dai, T.; Chen, J.; Li, X.; Li, T.; Liu, C.; Mcclements, D.J. Protein-polyphenol functional ingredients: The foaming properties of lactoferrin are enhanced by forming complexes with procyanidin. Food Chem. 2021, 339, 128145. [CrossRef]

29. González-Chávez, S.A.; Arévalo-Gallegos, S.; Rascón-Cruz, Q. Lactoferrin: Structure, function and applications. Int. J. Antimicrob. Agents 2009, 33, e1-e301. [CrossRef]

30. Abeyrathne, E.D.N.S.; Lee, H.Y.; Ahn, D.U. Egg white proteins and their potential use in food processing or as nutraceutical and pharmaceutical agents-A review. Poult. Sci. 2013, 92, 3292-3299. [CrossRef]

31. Guo, X.N.; Gao, F.; Zhu, K.X. Effect of fresh egg white addition on the quality characteristics and protein aggregation of oat noodles. Food Chem. 2020, 330, 127319. [CrossRef]

32. Sang, S.; Xu, D.; Ma, Y.; Jin, Y.; Wu, F.; Xu, X. Effect of egg yolk on the properties of wheat dough and bread. Food Biosci. 2020, 37, 100689. [CrossRef]

33. Li, J.; Zhai, J.; Gu, L.; Su, Y.; Gong, L.; Yang, Y.; Chang, C. Hen egg yolk in food industry-A review of emerging functional modifications and applications. Trends Food Sci. Technol. 2021, 115, 12-21. [CrossRef]

34. Wu, T.; Jiang, Q.; Wu, D.; Hu, Y.; Chen, S.; Ding, T.; Ye, X.; Liu, D.; Chen, J. What is new in lysozyme research and its application in food industry? A review. Food Chem. 2019, 274, 698-709. [CrossRef] [PubMed]

35. Salvatore, L.; Gallo, N.; Natali, M.L.; Campa, L.; Lunetti, P.; Madaghiele, M.; Blasi, F.S.; Corallo, A.; Capobianco, L.; Sannino, A. Marine collagen and its derivatives: Versatile and sustainable bio-resources for healthcare. Mater. Sci. Eng. C 2020, 113, 110963. [CrossRef] [PubMed]

36. Bhagwat, P.K.; Dandge, P.B. Collagen and collagenolytic proteases: A review. Biocatal. Agric. Biotechnol. 2018, 15, 43-55. [CrossRef]

37. Yang, R.; Zhou, Z.; Sun, G.; Gao, Y.; Xu, J. Ferritin, a novel vehicle for iron supplementation and food nutritional factors encapsulation. Trends Food Sci. 2015, 44, 189-200. [CrossRef]

38. Montero, P.; Ávalos, A.; Pérez-Mateos, M. Characterization of polyphenoloxidase of prawns (Penaeus japonicus). Alternatives to inhibition: Additives and high-pressure treatment. Food Chem. 2001, 75, 317-324. [CrossRef]

39. Nozawa, H.; Mamegoshi, S.I.; Seki, N. Partial purification and characterization of six transglutaminases from ordinary muscles of various fishes and marine invertebrates. Comp. Biochem. Physiol. Part B Biochem. Mol. Biol. 1997, 118, 313-317. [CrossRef]

40. Yang, N.; Fan, X.; Yu, W.; Huang, Y.; Yu, C.; Konno, K.; Dong, X. Effects of microbial transglutaminase on gel formation of frozen-stored longtail southern cod (patagonotothen ramsayi) mince. LWT_Food Sci. Technol. 2020, 128, 109444. [CrossRef]

41. Ahmed, Z.; Donkor, O.; Street, W.A.; Vasiljevic, T. Calpains- and cathepsins-induced myofibrillar changes in post-mortem fish: Impact on structural softening and release of bioactive peptides. Trends Food Sci. 2015, 45, 130-146. [CrossRef]

42. Xu, Y.; Zhao, Y.; Wei, Z.; Zhang, H.; Dong, M.; Huang, M.; Han, M.; Xu, X.; Zhou, G. Modification of myofibrillar protein via glycation: Physicochemical characterization, rheological behavior and solubility property. Food Hydrocoll. 2020, 105, 105852. [CrossRef]

43. Liu, H.; Zhang, H.; Liu, Q.; Chen, Q.; Kong, B. Filamentous myosin in low-ionic strength meat protein processing media: Assembly mechanism, impact on protein functionality, and inhibition strategies. Trends Food Sci. 2021, 112, 25-35. [CrossRef]

44. Zheng, H.; Han, M.; Yun, B.; Xu, X.; Zhou, G. Combination of high pressure and heat on the gelation of chicken myofibrillar proteins. Innov. Food Sci. Emerg. Technol. 2019, 52, 122-130. [CrossRef]

45. Motoki, M.; Seguro, K. Transglutaminase and its use for food processing. Trends Food Sci. 1998, 9, 204-210. [CrossRef]

46. Sun, X.D.; Arntfield, S.D. Gelation properties of chicken myoflbrillar protein induced by transglutaminase crosslinking. J. Food Eng. 2011, 107, 226-233. [CrossRef]

47. Lee, H.C.; Jang, H.S.; Kang, I.; Chin, K.B. Effect of red bean protein isolate and salt levels on pork myofibrillar protein gels mediated by microbial transglutaminase. LWT_Food Sci. Technol. 2017, 76, 95-100. [CrossRef]

48. Sun, X.D.; Arntfield, S.D. Gelation properties of myofibrillar/pea protein mixtures induced by transglutaminase crosslinking. Food Hydrocoll. 2012, 27, 394-400. [CrossRef]

49. Lee, H.C.; Kang, I.; Chin, K.B. Effect of mungbean [Vigna radiata (L.) Wilczek] protein isolates on the microbial transglutaminasemediated porcine myofibrillar protein gels at various salt concentrations. Meat Sci. 2015, 101, 112. [CrossRef]

50. Ramirez-Suarez, J.C.; Addo, K.; Xiong, Y.L. Gelation of mixed myofibrillar/wheat gluten proteins treated with microbial transglutaminase. Food Res. Int. 2005, 38, 1143-1149. [CrossRef]

51. Niu, H.; Xia, X.; Wang, C.; Kong, B.; Liu, Q. Thermal stability and gel quality of myofibrillar protein as affected by soy protein isolates subjected to an acidic $\mathrm{pH}$ and mild heating. Food Chem. 2018, 242, 188-195. [CrossRef]

52. Lin, D.; Zhang, L.; Li, R.; Zheng, B.; Rea, M.C.; Miao, S. Effect of plant protein mixtures on the microstructure and rheological properties of myofibrillar protein gel derived from red sea bream (pagrosomus major). Food Hydrocoll. 2019, 96, 537-545. [CrossRef]

53. Guo, A.; Xiong, Y.L. Myoprotein-phytophenol interaction: Implications for muscle food structure-forming properties. Compr. Rev. Food Sci. Food Saf. 2021, 20, 2801-2824. [CrossRef]

54. Guo, A.; Xiong, Y.L. Glucose oxidase promotes gallic acid-myofibrillar protein interaction and thermal gelation. Food Chem. 2019, 293, 529-536. [CrossRef]

55. Jia, N.; Wang, L.; Shao, J.; Liu, D.; Kong, B. Changes in the structural and gel properties of pork myofibrillar protein induced by catechin modification. Meat Sci. 2017, 127, 45-50. [CrossRef]

56. Cheng, J.; Zhu, M.; Liu, X. Insight into the conformational and functional properties of myofibrillar protein modified by mulberry polyphenols. Food Chem. 2020, 308, 125592. [CrossRef] 
57. Cao, Y.; True, A.D.; Chen, J.; Xiong, Y.L. Dual role (anti- and pro-oxidant) of gallic acid in mediating myofibrillar protein gelation and gel in vitro digestion. J. Agric. Food Chem. 2016, 64, 3054-3061. [CrossRef]

58. Bah, C.S.F.; Bekhit, A.E.A.; Carne, A.; Mcconnell, M.A. Slaughterhouse blood: An emerging source of bioactive compounds. Compr. Rev. Food Sci. Food Saf. 2013, 12, 314-331. [CrossRef]

59. Wismer-Pedersen, J. Use of haemoglobin in foods-A review. Meat Sci. 1988, 24, 31-45. [CrossRef]

60. Salvador, P.; Toldra, M.; Pares, D.; Carretero, C.; Saguer, E. Color stabilization of porcine hemoglobin during spray-drying and powder storage by combining chelating and reducing agents. Meat Sci. 2009, 83, 328-333. [CrossRef]

61. Zhang, H.; Li, P.; Kong, B.; Liu, Q.; Chang, Z.; Yang, H.; Jiang, Y. Application of glycosylated nitrosohemoglobin in meat batters: Color formation and antimicrobial activity. Adv. Mater. Res. 2012, 1915, 554-556. [CrossRef]

62. Zhang, H.; Li, P.; Kong, B.; Liu, Q.; Yang, H.; Zhao, Y.; Jiang, Y. Effect of glycosylated nitrosohemoglobin on quality of cooked meat batters during chill storage. Adv. J. Food Sci. Technol. 2013, 5, 19-23. [CrossRef]

63. Pereira, A.D.; Gomide, L.A.M.; Cecon, P.R.; Fontes, E.A.F.; Fontes, P.R.; Ramos, E.M.; Vidigal, J.G. Evaluation of mortadella formulated with carbon monoxide-treated porcine blood. Meat Sci. 2014, 97, 164-173. [CrossRef] [PubMed]

64. Fontes, P.R.; Gomide, L.A.M.; Fontes, E.A.F.; Ramos, E.M.; Ramos, A.L.S. Composition and color stability of carbon monoxide treated dried porcine blood. Meat Sci. 2010, 85, 472-480. [CrossRef] [PubMed]

65. Dong, J.; Zhou, Y.; Lu, Y.; Lv, Y.; Chi, Y.; He, Q. Effect of Tea Polyphenols on the Oxidation and Color Stability of Porcine Hemoglobin. Food Chem. 2019, 84, 2086-2090. [CrossRef] [PubMed]

66. Lee, Y.; Wang, R.; Nakai, S. Preparation of Colorless Globin from Bovine Hemoglobin using Sodium Alginate. Food Sci. 1990, 55, 577-578. [CrossRef]

67. Yang, J.; Lin, C. Functional properties of porcine blood globin decolourized by different methods. Int. J. Food Sci. Technol. 1998, 33, 419-427. [CrossRef]

68. Silva, J.G.; Morais, H.A.; Silvestre, M.P.C. Comparative study of the functional properties of bovine globin isolates and sodium caseinate. Food Res. Int. 2003, 36, 73-80. [CrossRef]

69. Shi, J.; Roos, A.; Schouten, O.; Zheng, C.; Vink, C.; Vonk, B.; Kliphuis, A.; Schaap, A.; Edens, L. Properties of hemoglobin decolorized with a histidine-specific protease. J. Food Sci. 2015, 80, 1202-1208. [CrossRef]

70. Silva, J.G.; Morais, H.A.; Oliveira, A.L.; Silvestre, M.P.C. Addition effects of bovine blood globin and sodium caseinate on the quality characteristics of raw and cooked ham pté. Meat Sci. 2003, 63, 177-184. [CrossRef]

71. Chen, H.; Xu, S.; Wang, Z. Interaction between flaxseed gum and meat protein. J. Food Eng. 2007, 80, 1051-1059. [CrossRef]

72. Cui, W.; Mazza, G.; Biliaderis, C.G. Chemical structure, molecular size distributions, and rheological properties of flaxseed gum. J. Agric. Food Chem. 1994, 42, 1891-1895. [CrossRef]

73. Trius, A.; Sebranek, J.G.; Lanier, T. Carrageenans and their use in meat products. Crit. Rev. Food Sci. Nutr. 1996, 36, 69-85. [CrossRef]

74. Wang, Y.; Zhou, Y.; Wang, X.; Li, P.; Xu, B.; Chen, C. Water holding capacity of sodium-reduced chicken breast myofibrillar protein gel as affected by combined $\mathrm{CaCl} 2$ and high-pressure processing. Int. J. Food Sci. Technol. 2020, 55, 601-609. [CrossRef]

75. Goemaere, O.; Glorieux, S.; Govaert, M.; Steen, L.; Fraeye, I. Phosphate elimination in emulsified meat products: Impact of protein-based ingredients on quality characteristics. Foods 2021, 10, 882. [CrossRef]

76. Baugreet, S.; Gomez, C.; Auty, M.A.E.; Kerry, J.P.; Hamill, R.M.; Brodkorb, A. In vitro digestion of protein-enriched restructured beef steaks with pea protein isolate, rice protein and lentil flour following sous vide processing. Innov. Food Sci. Emerg. Technol. 2019, 54, 153-161. [CrossRef]

77. Chandan, R.C. Milk composition, physical and processing characteristics. Manuf. Yogurt Fermented Milks 2006, 17-40. [CrossRef]

78. Pelegrine, D.H.G.; Gasparetto, C.A. Whey proteins solubility as function of temperature and pH. LWT-Food Sci. Technol. 2005, 38, 77-80. [CrossRef]

79. Tran Le, T.; Sabatino, P.; Heyman, B.; Kasinos, M.; Dinh, H.H.; Dewettinck, K.; Martins, J.; Van Der Meeren, P. Improved heat stability by whey protein-surfactant interaction. Food Hydrocoll. 2011, 25, 594-603. [CrossRef]

80. Thongngam, M.; McClements, D.J. Isothermal titration calorimetry study of the interactions between chitosan and a bile salt (sodium taurocholate). Food Hydrocoll. 2005, 19, 813-819. [CrossRef]

81. Zhang, H.; Yu, D.; Sun, J.; Guo, H.; Ding, Q.; Liu, R.; Ren, F. Interaction of milk whey protein with common phenolic acids. J. Mol. Struct. 2014, 1058, 228-233. [CrossRef]

82. Bujacz, A. Structures of bovine, equine and leporine serum albumin. Acta Crystallogr. Sect. D Biol. Crystallogr. 2012, 68, 1278-1289. [CrossRef]

83. Sun, C.; Yang, J.; Wu, X.; Huang, X.; Wang, F.; Liu, S. Unfolding and refolding of bovine serum albumin induced by cetylpyridinium bromide. Biophys. J. 2005, 88, 3518-3524. [CrossRef]

84. Dolinoy, D.C.; Huang, D.; Jirtle, R.L. Maternal nutrient supplementation counteracts bisphenol A-induced DNA hypomethylation in early development. Proc. Natl. Acad. Sci. USA 2007, 104, 13056-13061. [CrossRef]

85. Woodman, O.L.; Meeker, W.F.; Boujaoude, M. Vasorelaxant and antioxidant activity of flavonols and flavones: Structure-activity relationships. J. Cardiovasc. Pharmacol. 2005, 46, 302-309. [CrossRef]

86. Xiao, J.; Suzuki, M.; Jiang, X.; Chen, X.; Yamamoto, K.; Ren, F.; Xu, M. Influence of B-ring hydroxylation on interactions of flavonols with bovine serum albumin. J. Agric. Food Chem. 2008, 56, 2350-2356. [CrossRef] 
87. Smith, C.; Halliwell, B.; Aruoma, O.I. Protection by albumin against the pro-oxidant actions of phenolic dietary components. Food Chem. Toxicol. 1992, 30, 483-489. [CrossRef]

88. Choi, W.Y.; Kim, S.; Lee, N.; Kwon, M.; Yang, I.; Kim, M.J.; Cheong, S.G.; Kwon, D.; Lee, J.Y.; Oh, H.B.; et al. Amantadine-resistant influenza A viruses isolated in South Korea from 2003 to 2009. Antivir. Res. 2009, 84, 199-202. [CrossRef]

89. Holt, C. Structure and stability of bovine casein micelles. Adv. Protein Chem. 1992, 43, 63-151.

90. Kumar, S.; Clarke, A.R.; Hooper, M.L.; Horne, D.S.; Law, A.J.; Leaver, J.; Springbett, A.; Stevenson, E.; Simons, J.P. Milk composition and lactation of beta-casein-deficient mice. Proc. Natl. Acad. Sci. USA 1994, 91, 6138-6142. [CrossRef]

91. Udabage, P.; Mckinnon, I.A.N.; Augustin, M.A. Mineral and casein equilibria in milk: Effects of added salts and calcium-chelating agents. J. Dairy Res. 2000, 67, 361-370. [CrossRef]

92. Tsuchita, H.; Suzuki, T.; Kuwata, T. The effect of casein phosphopeptides on calcium absorption from calcium-fortified milk in growing rats. Br. J. Nutr. 2001, 85, 5-10. [CrossRef] [PubMed]

93. Lucey, J.A.; Fox, P.F. Importance of calcium and phosphate in cheese manufacture: A review. J. Dairy Sci. 1993, 76, 1714-1724. [CrossRef]

94. Lara-Castellanos, M.J.; Azuara, E.; Jimenez-Fernandez, V.M.; Luna-Solano, G.; Jimenez, M. Effect of casein replacement by modified casein on physicochemical, textural, sensorial properties and microbiological stability of fresh cheese. Int. Dairy J. 2021, 112, 104864. [CrossRef]

95. Gamiz-Hernandez, A.P.; Angelova, I.N.; Send, R.; Sundholm, D.; Kaila, V.R.I. Protein-induced color shift of carotenoids in $\beta$-crustacyanin. Angew. Chem. Int. Ed. 2015, 54, 11564-11566. [CrossRef] [PubMed]

96. Aisen, P.; Leibman, A. Lactoferrin and transferrin: A comparative study. Biochim. Biophys. Acta Protein Struct. 1972, 257, 314-323. [CrossRef]

97. Cunningham, F.E.; Proctor, V.A.; Goetsch, S.J. Egg-white lysozyme as a food preservative: An overview. World Poult. Sci. J. 1991, 47, 141-163. [CrossRef]

98. Fleming, A.; Allison, V.D. On a remarkable bacteriolytic element found in tissues and secretions. Proc. R. Soc. Lond. Ser. B Contain. Pap. Biol. Character 1922, 93, 306-317.

99. Yuceer, M.; Caner, C. Antimicrobial lysozyme-chitosan coatings affect functional properties and shelf life of chicken eggs during storage. J. Sci. Food Agric. 2014, 94, 153-162. [CrossRef]

100. Nakamura, S.; Kato, A.; Kobayashi, K. New antimicrobial characteristics of lysozyme-dextran conjugate. J. Agric. Food Chem. 1991, 39, 647-650. [CrossRef]

101. Jin, Y.; Zeng, Q.; Geng, F.; Ma, M. Characterization of the interaction between hen egg white lysozyme and ovalbumin. Food Biosci. 2020, 36, 100674. [CrossRef]

102. Zhao, Q.; Ding, L.; Xia, M.; Huang, X.; Isobe, K.; Handa, A.; Cai, Z. Role of lysozyme on liquid egg white foaming properties: Interface behavior, physicochemical characteristics and protein structure. Food Hydrocoll. 2021, 120, 106876. [CrossRef]

103. Dong, X.; Zhang, Y. An insight on egg white: From most common functional food to biomaterial application. J. Biomed. Mater. Res. Part B 2021, 109, 1045-1058. [CrossRef]

104. Pranata, M.P.; González-Buesa, J.; Chopra, S.; Kim, K.; Pietri, Y.; Ng, P.K.W.; Matuana, L.M.; Almenar, E. Egg white protein film production through extrusion and calendering processes and its suitability for food packaging applications. Food Bioprocess Technol. 2019, 12, 714-727. [CrossRef]

105. Huang, X.; Luo, X.; Liu, L.; Dong, K.; Yang, R.; Lin, C.; Song, H.; Li, S.; Huang, Q. Formation mechanism of egg white protein/K-carrageenan composite film and its application to oil packaging. Food Hydrocoll. 2020, 105, 105780. [CrossRef]

106. Tiimob, B.J.; Rangari, V.K.; Mwinyelle, G.; Abdela, W.; Evans, P.G.; Abbott, N.; Samuel, T.; Jeelani, S. Tough aliphatic-aromatic copolyester and chicken egg white flexible biopolymer blend with bacteriostatic effects. Food Packag. Shelf Life 2018, 15, 9-16. [CrossRef]

107. Ashie, I.N.A.; Simpson, B.K. Application of high hydrostatic pressure to control enzyme related fresh seafood texture deterioration. Food Res. Int. 1996, 29, 569-575. [CrossRef]

108. Busconi, L.; Folco, E.J.; Martone, C.B.; Sanchez, J.J. Postmortem changes in cytoskeletal elements of fish muscle1. J. Food Biochem. 1989, 13, 443-451. [CrossRef]

109. Hernández-Herrero, M.M.; Duflos, G.; Malle, P.; Bouquelet, S. Collagenase activity and protein hydrolysis as related to spoilage of iced cod (Gadus morhua). Food Res. Int. 2003, 36, 141-147. [CrossRef]

110. Harper, E. Collagenases. Annu. Rev. Biochem. 1980, 49, 1063-1078. [CrossRef]

111. Sae-Leaw, T.; Benjakul, S. Prevention of melanosis in crustaceans by plant polyphenols: A review. Trends Food Sci. 2019, 85, 1-9. [CrossRef]

112. Calvo, M.M.; Tzamourani, A.; Martínez-Alvarez, O. Halophytes as a potential source of melanosis-inhibiting compounds.mechanism of inhibition of a characterized polyphenol extract of purslane (Portulaca oleracea). Food Chem. 2021, 355, 129649. [CrossRef]

113. Harrison, P.M.; Arosio, P. The ferritin: Molecular properties, iron storage function and cellular regulation. Biochim. Biophys. Acta 1996, 1275, 161-203. [CrossRef]

114. Orino, K.; Lehman, L.; Tsuji, Y.; Ayaki, H.; Torti, S.V.; Torti, F.M. Ferritin and the response to oxidative stress. Biochem. J. 2001, 357, 241-247. [CrossRef] 
115. Moroz, C.; Chetrit, A.; Kahn, M.; Modan, B. FBL blood test as a predictive marker of breast cancer in high risk women. Med. Oncol. 1997, 14, 39-42. [CrossRef]

116. Zhou, J.; Wang, W.; Ma, G.; Wang, A.; He, W.; Wang, P.; Liu, Y.; Liu, J.; Sun, R. Gene expression of ferritin in tissue of the pacific white shrimp, Litopenaeus vannamei after exposure to $\mathrm{pH}$ stress. Aquaculture 2008, 275, 356-360. [CrossRef]

117. Maiti, B.; Khushiramani, R.; Tyagi, A.; Karunasagar, I.; Karunasagar, I. Recombinant ferritin protein protects penaeus monodon infected by pathogenic Vibrio harveyi. Dis. Aquat. Org. 2010, 88, 99-105. [CrossRef]

118. Chen, X.; Li, Y.; Chang, X.; Xie, X.; Liang, Y.; Wang, K.; Zheng, W.; Liu, H. A cqferritin protein inhibits white spot syndrome virus infection via regulating iron ions in red claw crayfish cherax quadricarinatus. Dev. Comp. Immunol. 2018, 82, 104-112. [CrossRef]

119. Lemonnier, H.; Wabete, N.; Pham, D.; Lignot, J.H.; Barri, K.; Mermoud, I.; Royer, F.; Boulo, V.; Laugier, T. Iron deposits turn blue shrimp gills to orange. Aquaculture 2021, 540, 736697. [CrossRef]

120. Cianci, M.; Rizkallah, P.J.; Olczak, A.; Raftery, J.; Chayen, N.E.; Zagalsky, P.F.; Helliwell, J.R. The molecular basis of the coloration mechanism in lobster shell: $\beta$-crustacyanin at 3.2-resolution. Proc. Natl. Acad. Sci. USA 2002, 99, 9795-9800. [CrossRef] 